\title{
Spatial Relations in the Indonesian Locative Preposition of "Di Atas": a Study of Cognitive Semantics
}

\section{Joko Kusmanto ${ }^{a 1^{*}}$, Sarmedi Agus Siregar ${ }^{\mathrm{a} 2}$, Mariahati ${ }^{\mathrm{b3}}$}

Mechanical Engineering Study Program, Medan State Polytechnic ${ }^{\text {a }}$

Accounting Study Program, Medan State Polytechnic ${ }^{\mathrm{b}}$

jokokusmanto@polmed.ac.id ${ }^{1 *}$; sarmediagus@polmed.ac.id ${ }^{2}$; mariahati@polmed.ac.id ${ }^{3}$

*author correspondence

\begin{tabular}{ll}
\hline \multicolumn{2}{c}{ Informasi artikel } \\
\hline Sejarah artikel: & \\
Diterima: & 30 Januari 202I \\
Revisi: & 4 Juli 202I \\
Dipublikasikan: & 30 Oktober 202I \\
\hline
\end{tabular}

\section{Kata kunci:}

Relasi spasial

Skema citra

Preposisi

Semantik kognitif

metafora

\begin{abstract}
Penelitian ini mengkaji relasi spasial preposisi "di atas" dalam bahasa Indonesia menggunakan teori semantik kognitif. Penelitian ini bertujuan untuk menemukan (i) stuktur konseptual relasi spasial preposisi "di atas" dan (ii) perluasan penggunaannya dalam pemetaan konseptual. Penelitian ini menggunakan metode deskriptif kualitatif. Sumber data kognitif dikumpulkan dari tiga kelompok subjek yang masing-masing terdiri atas sepuluh orang. Tiga kelompok subjek ini sekaligus juga digunakan sebagai tiangulasi sumber untuk mengelisitasi struktur konseptual penggunakan preposisi “di atas”. Sementara itu, data perluasan penggunaan dalam pemetaan konseptual dikumpulkan dari media-media daring. Hasil penelitian menunjukkan bahwa struktur konseptual preposisi "di atas" memiliki dua jenis skema citra, yaitu (i) skema citra VERTIKALITAS berdasarkan oreintasinya dan (ii) skema citra ANTARA dan skema citra TOPANGAN berdasarkan topologinya. Dua skema citra tersebut bersifat umum dan dispesifikasi menjadi satuan lingual definitif berdasarkan perbedaan persepsi penutur terhadap kedudukan entitas yang berelasi. Temuan penelitian penting lainnya adalah bahwa preposisi yang selama ini dipandang sebagai kata tertutup dapat digunakan secara metaforis melalui pemetaan konseptual. Ini menunjukkan bahwa preposisi memiliki peran penting dalam menstrukturkan pikiran manusia. Hasil penelitian juga menemukan dan menguatkan sifat konstrual dalam konseptualisasi makna.
\end{abstract}

\section{ABSTRACT}

\section{Keywords:}

Spatial relation

Image schema

preposition

cognitive semantics

metaphor

\begin{abstract}
This study examines the spatial relation of the preposition "di atas" (above, over, on) in Indonesian using cognitive semantic theory. This study aims to discover (i) the conceptual structure of the preposition "di atas" spatial relation and (ii) its extended use in the conceptual mapping. This study used descriptive qualitative method. The cognitive data were collected from three groups of subjects, each consisting of ten people. These three groups of subjects are also used as the source triangulation to elicit the conceptual structure of the preposition "di atas" (above, over, on). Meanwhile, the data on the preposition's extended use in the conceptual mapping were collected from online media. The results suggest that the conceptual structure of the preposition "di atas" (above, over, on) has two kinds of image schemas, namely (i) the VERTICALITY image schema which is based on its orientation and (ii) the ANTARA image schema and the TOPANGAN image schema which are based on its topology. The two kinds of image schemas are general in nature and are specified as definitive lingual units based on the speaker's different perceptions of the position of the related entities. Another important research finding is that prepositions that have been seen as closed words can be used metaphorically through conceptual mapping. This shows that prepositions have an important role in structuring human mind. The results of the study also found and reinforced the construal nature of meaning conceptualization.
\end{abstract}

Copyright (C) 2018 Universitas Ahmad Dahlan. All Right Reserved

\section{Introduction}

Preposition is a term that is attached to the lexical category of adposition whose position is before the nominal phrase (NP) in a phrase construction (Payne, 20II). The phrase construction in syntax is known as prepositional phrase (PP) which consists of "preposition" as the head and NP as the argument. If a phrase construction syntactically places the adposition after the object of the adposition, the adposition is called a 
"postposition". Prepositions and postpositions have the same function in the construction of adpositional phrases. The term "adposition" is a neutral term used to encompass the terms preposition and postposition. The term "preposition", thus, is directly related to its position in the construction of the adpositional phrase.

Because prepositions can be the head of a phrase construction, namely the head of PP, prepositions are classified into lexical categories other than Noun, Verb, Adjective, and Adverb (van Gelderen, 2010:34). It means that prepositions have their own lexical meanings. Although prepositions have lexical meanings, they are one of the closed word classes which are limited in number and do not have the possibility of increasing (Chaer, 2008). It is not surprising that prepositions receive less attention in linguistic studies, especially if this phenomenon is associated with the view that PP does not have a central role in the syntactic construction of the Indonesian language (Mulyadi, 20I2).

The view that FP does not have a central role in the construction of Indonesian syntax needs to be elaborated. PP does not have a central role in syntactic construction if it does not have a central syntactic function in a sentence, such as the Subject, Predicate, or Object syntactic functions. If a PP occupies a syntactic function as a Predicate, PP certainly has a central role in syntactic construction as in sample sentence (I)

\section{(I). a. Buku saya berada di atas meja kemarin. \\ (My book was on the table yesterday.) b. * Buku saya berada kemarin. \\ (My book was yesterday.)}

Example (I) shows that PP (di atas meja) cannot be eliminated because PP in the sample sentence (I) has a central role. It means that PP is not always a non-central constituent in the syntactic construction of Indonesian language.

To date, there are three focuses in prepositional studies in Indonesian language. The three focuses of the study include (i) types of prepositions, (ii) syntactic functions of prepositions and PP, and (iii) meaning of prepositions. All three are briefly summarized in the research conducted by Effendi \& Aritonang (I99I). Studies on the types of prepositions discuss the forms of prepositions, such as whether the preposition is in the form of single or compound preposition. Studies on preposition syntactic function discuss (i) how prepositions function in PP construction and (ii) how PP functions in sentence construction. Meanwhile, studies on the meaning of prepositions only discuss the general meaning of prepositions in a sentence.

Recent Indonesian studies on prepositions are still dealing with the three focuses. In fact, some are reduplicative, such as the research conducted by Kurniasih (2017). Other prepositional studies can generally be grouped into four categories. The first is research on the use of prepositions in a text with certain registers, such as the research by Kurniasih (2017). The second is a contrastive research between prepositions in Indonesian language and those in other languages, such as the research conducted by Mas Kusumaningrat (2015) and Rini (2009). The third is syntactically prepositional research, such as that by Mulyadi (2012) and Yusof (1996). The last one is prescriptive preposition research such as the research conducted by Sugiarti \& Ngaisah (2018).

This study examines the spatial relation of locative preposition "di atas" (above, over, on) based on the cognitive semantic theory, a theory that is different from the ones mentioned above and is still rarely used in Indonesia (Kusmanto, 20I7). Similar studies are still rare and one of them is the research by Mardiah \& Muta'ali (2020) which examines the preposition "pada" (at). Although their research uses both "spatial relation" and "cognitive semantics" references, their research does not elaborate on the spatial meaning of the preposition "pada" (at) with the theoretical framework of "embodiment" and "image schema" as the bases to reveal the meaning of the preposition. Meanwhile, embodiment and image schema are important conceptual frameworks in cognitive semantics (Auer \& Schmidt, 2010; Evans \& Green, 2006; Hampe \& Grady, 2005; K. S. Mix et al., 2010; K. S. Mix et al., 2009; Tyler \& Evans, 2003)

The use of cognitive semantic theory in this study is based on one important theoretical reason. Cognitive semantic theory views prepositions as a very important feature in a language. Prepositions are language features that are directly related to the existence of space and the spatial relations between entities in space. Cognitive semantics views space as one of the essential entities in human life (Brenda, 20I4; Svorou, I994).

In Kant's philosophy, space is "a universal cognitive primitive" (Hickmann \& Robert, 2006, p. I). In fact, space is said to be "an important part of the background for all conceptualization and meaning" (Zlatev, 2007, p. 320). In fact, Levinson \& Wilkins (2006) state that spatial cognition is a fundamental prerequisite for every living species that has mobility. It means that humans have cognitive devices that enable them to perceive, conceptualize, represent, and symbolize space as a spatial cognition. For humans, spatial cognition has an important role in the process of thinking and reasoning (Clark, 2010). In fact, Clark (2010, p. II) states that "[T] he cognitive functions 
of space and language are strikingly similar". Therefore, the language aspect related to space is also a significant concern in research.

Research on prepositions concerning cognitive semantic theory aims to examine how space is conceptualized in human cognition. In other words, prepositions used in natural utterances are access to find out "patterns of thought" (Evans \& Green, 2006, p. 5). The real meaning of prepositions is the conceptualization of the use of prepositions stored in the speaker's cognition. The conceptualization in question is in the form of a cognitive order of spatial relations between entities in speakers of a language. This discussion concerning spatial relations is related to four principles (Evans \& Green, 2006, p. 157). The four principles are (i) meaning construction being a product of conceptualization, (ii) meaning being represented encyclopedically, (iii) meaning structure being in the form of conceptual structure, and (iv) conceptual structure being embodied.

It has been previously mentioned that the preposition being studied here is the Indonesian preposition " $d i$ atas" (above, over, on). The preposition "di atas" is a lingual symbol that represents a certain spatial relation concept. Spatial relations are a logical consequence of (i) awareness of the existence of space and (ii) awareness of the existence of entities in a certain configuration. The questions that arise are (i) how the conceptual structure in the spatial relation of the preposition "di atas" is and (ii) whether the preposition "di atas" can be extended metaphorically in conceptual mapping.

Thus, the purpose of this study is (i) to explain the conceptual structure of the spatial relations in the cognition of Indonesian speakers about the preposition "di atas" and (ii) to find out whether the use of the preposition "di atas" can be extended metaphorically. In detail, the conceptual structure of the preposition "di atas" studied in this study includes two things, (i) the conceptualization of the image schema of the spatial relation of the preposition "di atas" and the symmetrical relation between entities related by the preposition "di atas" and (ii) the extension of the use of preposition "di atas" in conceptual mapping.

Based on this explanation, the preposition "di atas" can be regarded as a lingual symbol to present the conceptualization of a phenomenon, namely spatial relation configuration phenomenon. Conceptualization is a general term used to refer to fundamental cognitive processes, such as schematization and categorization (Sharifian, 20I I). In other words, schematization and categorization are parts of the fundamental conceptual structure in the conceptualization or concept formation process. Based on this brief understanding of conceptualization, the meaning of a lingual unit is essentially a concept, the result of a conceptualization that occurs and is stored in cognition. Thus, it can be said that the concept (meaning) of the preposition "di atas" is the result of a conceptualization of patterned empirical experiences (Johnson, 1987). Different from objectivism in semantics, cognitive semantics argues that meaning (the concept of a lingual unit) is construal. Speakers of different languages may perceive and conceptualize similar empirical experiences differently (Croft \& Cruse, 2004).

The concept (meaning) of a lingual unit has a conceptual structure. The most basic conceptual structure in conceptualization is built on schematization, a cognitive process in the systematic selection of certain aspects of "a referent scene to present the whole, disregarding the remaining aspects" (Talmy, I983, p. 225). The process of forming this schema is made possible through categorization. Croft \& Cruse (2004, p. 54) believe that categorization is "the most fundamental judgment of comparison". Categorization serves to reduce a series of stimuli whose detailed differences may be unlimited into equivalent and limited categories (Medin, I989; Rosch, 1978). Furthermore, Medin (1989) states that categorization does not always have to correspond to what is in the world because humans can create an imaginary and not only find structures that exist in the world. Some examples are the mental representations of unicorns, ninja turtles, or mermaids. Both schematization and categorization are construal. Thus, schematization and categorization of the same phenomenon can differ between speakers of one language and those of other languages.

Meanwhile, categorization reduces the similarities and differences contained in various configurations of spatial relations as different experiences into a series of classifications. This process implies that the preposition "di atas" contains a rich conceptual category. The conceptual category symbolized by the lingual unit of the preposition "di atas" is essentially the reduction result of a series of different spatial relation configurations. However, the differences in a series of spatial relation configurations are ignored and are generally reduced to the same category and symbolized by a lingual unit known as the preposition "di atas". This categorization process can be respresented in Figure I. 


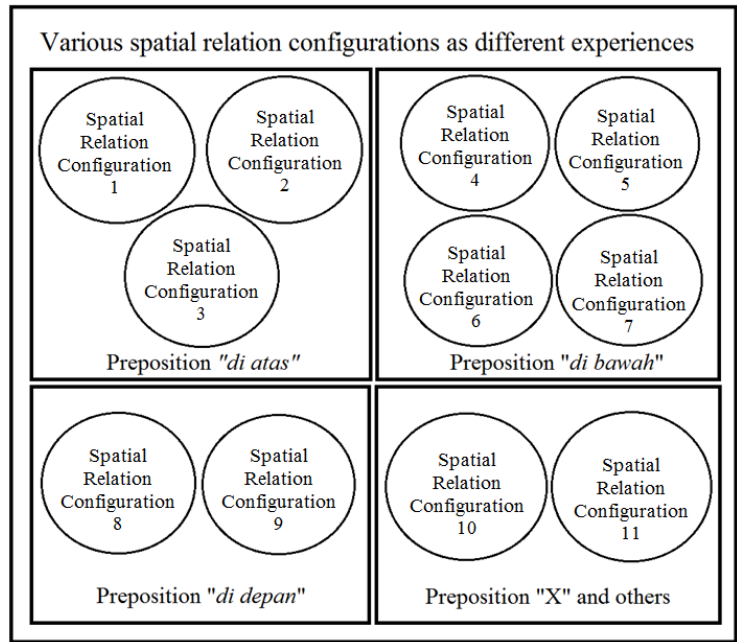

Figure I. Visualization of Categorization Process of Spatial Relation Configurations

Categorization simultaneously involves another cognitive process called schematization (Croft \& Cruse, 2004). Schematization produces a schema, a mental representation in the form of a set of knowledge structures of various objects or events and is attached to these objects or events with "default assumptions about their characteristics, relationships, and entailments under conditions of incomplete information" (DiMaggio, 1997, p. 269). As stated by Johnson (1987:I4), the embedding of these characteristics and their entailments can be done because schema is "a recurring, dynamic pattern of our perceptual interactions and motor programs that gives coherence and structure to our experience". Thus, schema is a structure in human cognition that functions to assist humans (i) in organizing their knowledge about people, places, objects, circumstances, and events and (ii) in understanding new information. Schema also produces represented mental image entailments and their relations. This is why schema is also known as image schema in cognitive semantics.

An example is the VERTICALITY schema. This schema (mental representation) is the result of the conceptualization of hundreds or even thousands of perceptual experiences related to structures experienced by humans, such as seeing trees, human awareness to stand up, climbing stairs, climbing electricity poles, measuring height and so on. This VERTICALITY schema is an abstract knowledge structure as a result of the conceptualization of various daily experiences (Johnson, 1987).

The mental representation in the form of image schema is also construal. It means that, although the VERTICALITY schema is generally universal, the spatial relations between entities in the VERTICALITY schema can be conceptualized differently in different languages. Related to the problems studied in this paper, some questions arise, for example, whether the conceptual structure of Indonesian preposition "di atas" is the same as the structure of the English preposition "on". Therefore, this paper will also address this issue to prove that the conceptual structure is construal.

Besides being general in nature, VERTICALITY schema also has a more detailed conceptual substructure. This conceptual substructure is related to how the entities in a spatial relation configuration are perceived. An example is a configuration of spatial relations between the entities "table" and "bottle" in Figure 2.

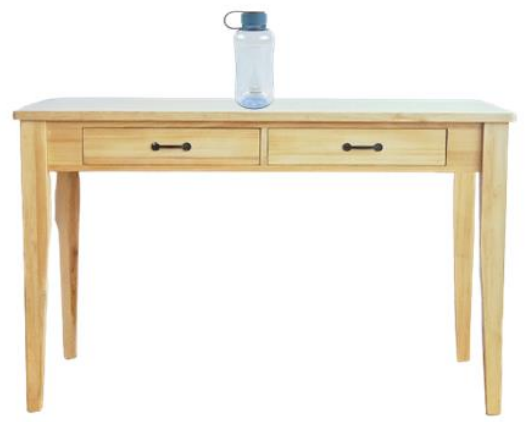

Figure 2. Configuration of Spatial Relation between Bottle and Table

The general schema of the spatial relation between the bottle and table in Figure 2 is the VERTICALITY schema. The question is whether the table entity and the bottle entity are perceived with the same or different 
status in the spatial relation? In other words, do table entity and bottle entity have a symmetrical or asymmetrical position?

If the two entities are perceived with a symmetrical status, we will find statements (2) to reveal the configuration of spatial relations in Figure 2.

\section{(2). a. Botol itu berada di atas sebuah meja. \\ (The bottle is on the table.) \\ b. "Meja itu berada di bawah sebuah botol. \\ ( The table is under the bottle.)}

Statement (2.a) is natural in Indonesian language, while speech (2.b) is not a natural statement in Indonesian language. It means that the two entities are perceived to have asymmetrical status. The asymmetry of the relationship between the two entities in a spatial relation is a form of conceptual structure in prepositions. The preposition "di atas" used to relate the spatial configuration in Figure 2 is the result of how the symmetry of the two entities is perceived. Thus, the realization of statement (2.a) as a representation of the configuration of spatial relations of Figure 2 does not just happen or is not random; instead, it is based on a cognitive motivation (Croft \& Cruse, 2004; Evans, 2012; Evans \& Green, 2006; Munnich et al., 200I; Tyler \& Evans, 2003).

The asymmetrical status of entities in a spatial relation is known as Figure and Ground in cognitive semantics (Croft \& Cruse, 2004; Evans \& Green, 2006) or Trajectory and Landmark (Talmy, 1983, 2000). Indonesian speakers will perceive the table entity as the Landmark and the bottle entity as the Trajectory in the configuration of spatial relation in Figure 2.

It shows that the configuration of the spatial relation between the table entity and the bottle entity results in a schema where one entity acts as a TRAJECTORY and the other as a LANDMARK. The VERTICALITY schema is the result of the classification of geometric configurations and the TRAJECTORY/LANDMARK schema is the result of the symmetrical categorization of the relation between entities. The TRAJECTORY/LANDMARK schema is one part of the conceptual structure that determines whether a configuration of spatial relation is represented in "x di atas $y$ " or "y di bawah $x$ ". Although the phenomenon of spatial configuration is the same, the spatial relation is cognitively conceptualized differently.

Based on the description and brief explanation of the image schema and the symmetry related to the use of the preposition "di atas", it is clear that this study generally provides novelty in two respects. First, this paper describes the conceptual structure of the Indonesian preposition "di atas" with cognitive semantic theory. Second, this study presents new data and findings for researchers of spatial relations in cognitive semantics.

\section{Method}

The research was conducted with qualitative descriptive method. Two types of data were used in this study, namely (i) cognitive data and (ii) lingual data. Cognitive data was used to reveal the conceptual structure of the preposition "di atas" and lingual data was used to examine the extent of the use of the preposition "di atas" in conceptual mapping. The cognitive data were obtained from three groups of subjects. The three subject groups consist of ten people each, the groups are called Group A, Group B, and Group C. All subjects were Indonesian speakers who used Indonesian in their daily lives.

Cognitive elicitation data were obtained by using pictorial instrument and questions and answers. Group A was utilized to elicit the use of the preposition "di atas" with pictorial instruments. Group A was asked to provide a statement based on the verbal description included in the pictorial instrument that was shown to them. Group B was aimed to elicit the use of the preposition "di atas" through verbal descriptions in the pictorial instrument given to group A. Group B was asked to make sketches or drawings on the verbal descriptions given to them. Group C was utilized to elicit the symmetry of related entities. The cognitive elicitation data also serves as a form of source triangulation.

Meanwhile, the lingual data on the extent of the use of the preposition " di atas" were collected from four online media, namely (i) Kompas, (ii) Republika, (iii) Tribun, and (iv) Waspada. The data was taken from the headlines of each data source for a period of two months.

\section{Result and discussion}

\section{Image schema of the preposition "di atas"}


The image schema of the preposition "di atas" can be analyzed from two points of view. The first point of view is based on its orientation and the second point of view is based on its topology.

\section{I.I. Based on its orientation}

The conceptual structure of the preposition "di atas", as described earlier, is classified into VERTICALITY image schema, which is a mental representation that structures various spatial relation configurations of various phenomena, both for objects and events. This image schema emerges from "our tendency to employ an UP-DOWN orientation in picking out meaningful structures of our experience" (Johnson, 1987, p. xiv). This schema is based on the physical experience of human awareness of the figure that has a certain structure, the experience of growth of the figure structure, as well as various objects and events. All these various experiences are conceptualized by orientation into the same schema, namely the VERTICALITY image schema as visualized simply in Figure 3.

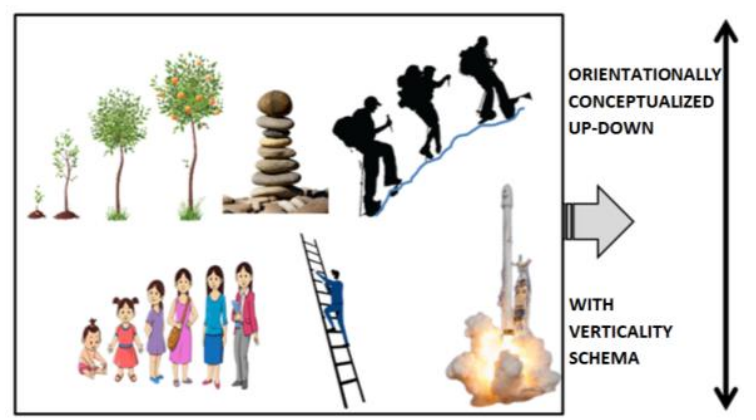

Figure 3. Conceptualization in VERTICALITY Schema

To generate the speaker's knowledge about the orientation schema of the preposition "di atas", the research subjects were given twenty statements in which there were prepositions "di atas (on, above, over), di bawah (under, below), di depan (in front of), di samping (beside, next to), and di belakang (behind)". The research subjects were then asked to choose the orientation of the relationship between entities that matched the statements. The statements were shown to the subject one by one. After each statement was shown, three orientation schemas were shown to the subject. Subjects were asked to choose which orientation schema represented the relationship between entities in the twenty statements. The three orientation schemas shown to the research subjects to choose from after reading each statement are presented in Figure 4.

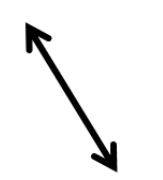

a. diagonal

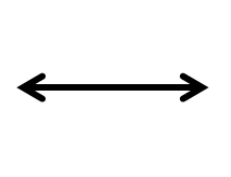

b. horizontal

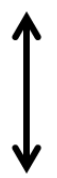

c. vertical

Figure 4. Urientation Relation Schemas

The results of data analysis suggest that all research subjects relate the prepositions "di atas and di bawah" with VERTICALITY schema. Meanwhile, the research subjects relate all statements with the prepositions "di depan, di samping, and di belakang" with HORIZONTAL scheme. Thus, the mental representation generated by the preposition "di atas" is VERTICALITY image schema. It implies that the conceptualization that occurs in the cognition of Indonesian language speakers with the use of the preposition "di atas" is a vertically-oriented relation schematization.

The VERTICALITY image schema is a general schema. The image schema is the result of the categorization of spatial relations which is schematized differently from other orientations, such as horizontal orientation. Since the VERTICALITY image schema is general, the mental representation of the generated spatial relations is also general. This image schema is only a mental representation of spatial relations that are schematized VERTICALLY which, in detail, can cover prepositions such as "di atas and di bawah".

\section{I.2. Based on its topology}

The VERTICALITY image schema is a mental representation that structures various configurations of spatial relations based on their orientation. This image schema emerges from "our tendency to employ an UP- 
DOWN orientation in picking out meaningful structures of our experience" (Johnson, 1987, p. xiv). This schema is based on the physical experience of human awareness of a figure that has a certain structure, the experience of growth of the figure structure, as well as various objects and events. All the various experiences are conceptualized in an orientated manner into the same schema, namely the VERTICALITY image schema as visualized in Figure 4. The VERTICALITY image schema is two-dimensional with a series of relations in it as symbolized in the lingual prepositions "diatas" and "di bawah". Can the verbal symbols of the prepositions "diatas" and "di bawah" as a continuum represent all spatial relations in VERTICALITY image schema? To further examine the conceptual structure of the preposition "di atas", it is necessary to look at the concept of topology in the preposition. In this case, the research subjects were divided into two groups. Half (group A) were given ten pictures and asked to decide whether the verbal descriptions accompanying the pictures were acceptable. An example of the research instrument is presented in Figure 5.

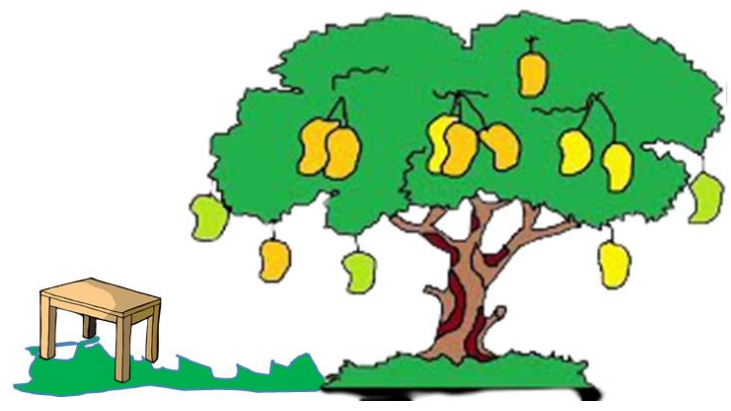

Buah-buah mangga itu bergelantung di atas meja. (The mangoes hang above the table.)

Figure 5. Elicitation of the Conceptual Structure of the Preposition "di atas" Based on Topology I

According the elicitation data in Figure 5, the research subjects in group A stated that the verbal description under the picture was incorrect. The spatial relation between mangoes and the table cannot be represented by using the preposition "di atas". Group B was then asked to sketch a picture to represent the verbal statements contained in the pictures given to group A. For example, in relation to Figure 5, group B was given a verbal statement (3).

(3) Buah-buah mangga itu bergelantung di atas meja.

(The mangoes hang above the table)

In carrying out this task, it was ensured that group B certainly did not communicate with group A to discuss anything related to the task. Thus, group B did not know the pictures given to group A at all.

In general, the research respondents in group B provided pictures with a similar concept as shown in Figure 6. The concept consists of three things. First, there is a table. Second, there are hanging mangoes. Third, there is space between the mangoes and the table.

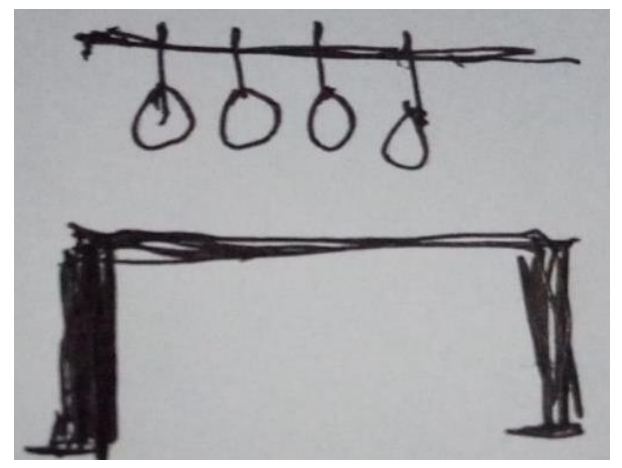

Figure 6. Elicitation Result of the Verbal Statement in Figure 5

The elicitation results also provide an answer why the research subjects did not orientationally relate the prepositions "di atas" and "di bawah" with a diagonal orientation. The diagonal orientation allows the spatial 
relation as shown in Figure 5. It is possible that it will differ from the conceptual structure of the preposition "ke atas" (upwards) which allows for a diagonal orientation. This is a problem of a separate study.

The elicitation data analysis for the movement related to the preposition "di atas" also uses a similar schema to Figure 4 and Figure 5. The elicitation data for group A is presented in Figure 7 and the elicited image from group B is presented in Figure 8.

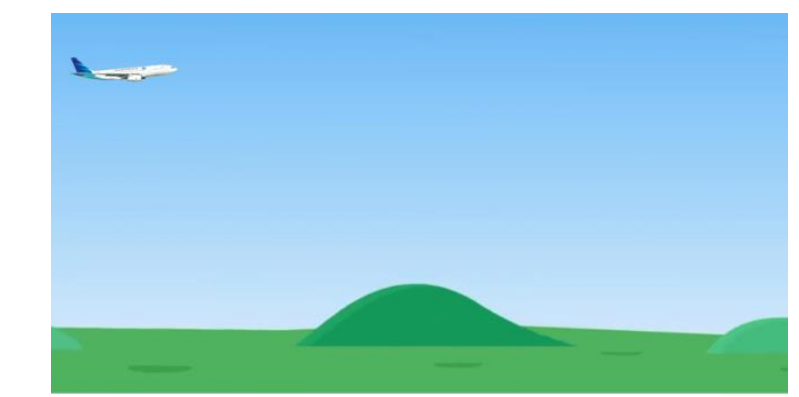

Pesawat terbang itu terbang melintas di atas bukit.

(The airplane flies over the hill.)

Figure 7. Elicitation of the Conceptual Structure of the Preposition "di atas" Based on Topology 2

All subjects in group A stated that the verbal description was not appropriate to represent the relationship between the airplane and the hill. They stated that the verbal description "Pesawat terbang itu akan melintas di atas bukit" (The plane is going to fly over the hill) is a more appropriate description. The elicitation results show that the image schema of the spatial relation of the preposition "di atas" is vertical, both based on its orientation and topology. Different from elicitation in Figure 5, elicitation in Figure 7 can be added with the lingual unit "akan" (is going to) because the airplane entity is in motion.

Meanwhile, when group B was given a verbal description of "Pesawat terbang itu melintas di atas bukit" (The airplane flies over the hill), all research subjects in group B gave their pictures as presented from one of the elicitation images in Figure 8.

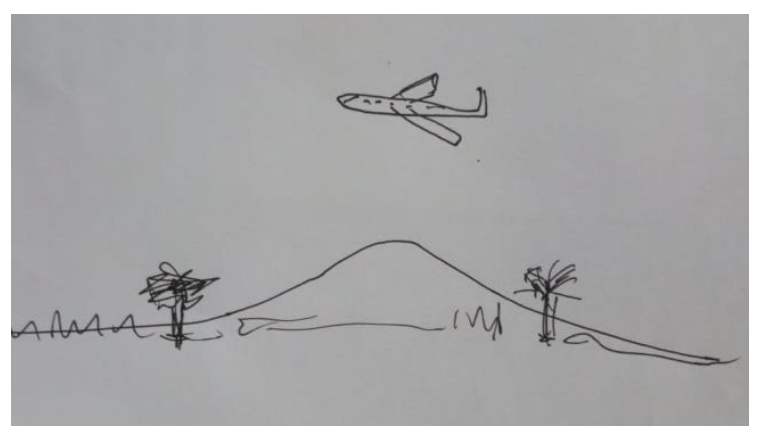

Figure 8. Elicitation Result from thr Verbal Statement in Figure 7

The elicitation analysis results clearly show that the spatial relation image schema in Figure 7 and Figure 8 generated by the preposition "di atas" is the same image schema based on its topology.

The image schema topology of the preposition "di atas" as shown in Figure 5 and Figure 8 is an "antara topology" (between topology). The "antara topology" is the relation between entities in the conceptual structure of the preposition "di atas" which (i) is vertically oriented and (ii) has space between the two. In addition to representing the "antara topology", the conceptual structure of the preposition "di atas" also represents the "topangan topology" (support topology). The analysis of elicitation results in group A and group B shows the same results as "antara topology" elicitation. The elicitation results of "topangan topology" are shown in Figures 9 and IO. 


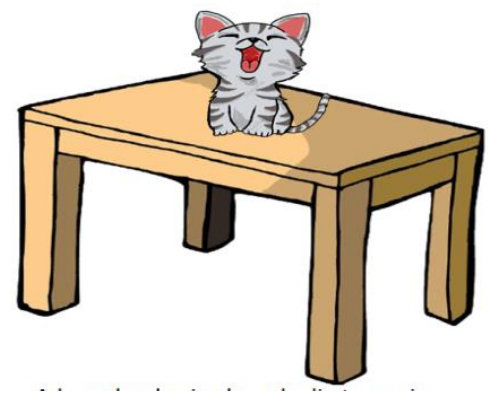

Ada seekor kucing berada di atas meja.

(There is a cat on the table.)

Figure 9. Conceptual Structure Elicitation of the Preposition "di atas" based on topangan topology

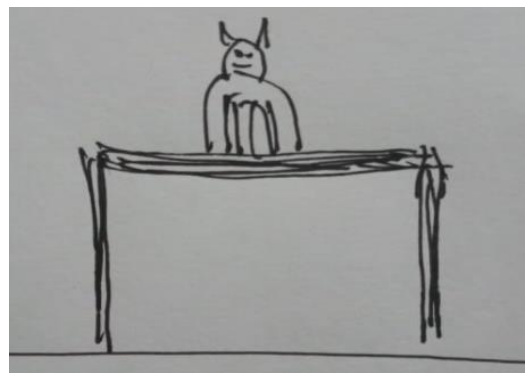

Figure I0. Elicitation Result from thr Verbal Statement in Figure 9

The analysis results of the image schema of the preposition "di atas" based on its topology show that the preposition "di atas" symbolizes two different topologies. The two topologies are (i) Antara Topology (TA) and (ii) Topangan Topology (TT). The TA image schema is shown in Figure 6 and Figure 8. Meanwhile, the TT image schema is shown in Figure I0. To distinguish the two topological image schemas for the preposition "di atas" in a communication, Indonesian speakers rely on other representations. The other representations can be in the form of a lingual context or a paralingual context. The lingual units "bergelantungan" (hang) and "terbang" (fly) become the lingual context to understand the topology represented by the preposition "diatas" as in Figures 6 and 8.

Elicitation of the conceptual structure of the preposition "di atas" based on this orientation and topology also shows the thesis that conceptualization is construal. It is clear that the preposition "di atas" is used to symbolize two different topologies of spatial relations, namely TA and TT. In other words, Indonesian speakers conceptualize the two different topologies of spatial relations as the same concept. This is different, for example, for English speakers (Kusmanto, 2017). TA, in English, is symbolized by the preposition "above" and TT is symbolized by the preposition "on". Thus, English speakers do not need both lingual and paralingual contexts to understand a spatial relation with the VERTICALITY image schema. If the preposition "above" is used, the spatial relation symbolized must have a TA topology. Likewise, if the preposition "on" is used, the symbolized spatial relation must have a TT topology.

Furthermore, the TT image schema for the preposition "on" in English is also different from the image schema for the TT preposition "above" in Indonesian language. The image schema of the TT for the preposition "on" in English is also not based on the rigid VERTICALITY image schema as shown in Figure II (Kusmanto, 2017). 

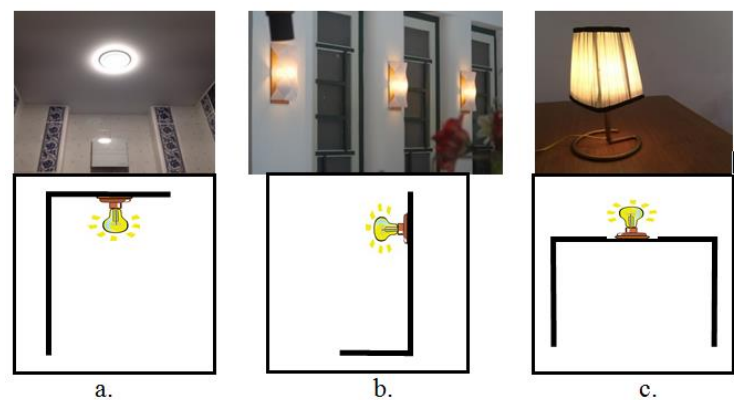

Figure II The Use of Preposition "on" in English

The three configurations of spatial relations involving the light entity in Figure II are perceived as having the same spatial relation by English speakers. It is indicated by the use of the same lingual symbol, namely the preposition "on" as in the example of lingual realization (3).
(3). a. The lamp is on the ceiling.
b. The lamp is on the wall.
c. The lamp is on the table.

Meanwhile, in Indonesian the preposition "di atas" can only be used to describe the spatial relation (c) in Figure II. Therefore, the lingual description of the preposition "on" in (3) cannot all be translated into Indonesian with the preposition "di atas" as in lingual realization (4).

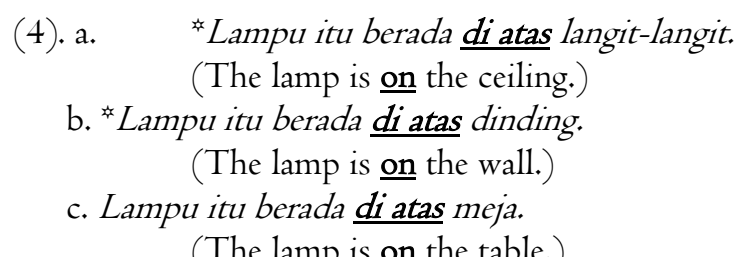

(The lamp is on the table.)

The results of this analysis prove that meaning is the result of cognitive conceptualization that is construal. The same configuration of spatial relations can be perceived and then conceptualized differently by speakers of different languages. This knowledge definitely helps English speakers when learning Indonesian and, conversely, also helps Indonesian speakers when learning English.

\section{Symmetry in the Spatial Relation of the Preposition "di atas"}

To see if speakers have different perceptions of the entities related to the preposition "di atas", one subject group (group C) was used to elicit ten pictures that represent a spatial relation with a vertical orientation image schema and "antara topology" and "topangan topology". The pictures did not have verbal descriptions. Subjects in group $\mathrm{C}$ were asked to provide a verbal description of the relationship between the entities in the pictures in one sentence as short as possible. One of the pictures given to the subjects is shown in Figure 9.

The results of data elicitation with Figure 9 show that all subjects in group $\mathrm{C}$ stated that the relationship between entities in Figure 9 was a relationship between entities with the preposition "diatas". Verbal descriptions given by all subjects in group $\mathrm{C}$ are presented in data (5).
(5). a. Ada seekor kucing di atas sebuah meja.
(There is a cat on the table.)
b. Ada seekor kucing di atas meja.
(There is a car on the table)
c. Di atas meja ada seekor kucing.
(On the table is a cat.)
d. Kucing itu berada di atas meja.
(The cat is on the table.)
e. Kucing itu asyik duduk di atas meja.
(The cat happily sits on the table.)
f. Kucing itu mengeong di atas meja. 
(The cat meows on the table.)

g. Kucing itu duduk di atas meja.

(The cat sits on the table.)

h. Ada seekor kucing duduk di atas meja.

(There is a cat sitting on the table.)

i. Kucing hitam itu ada di atas meja.

(The black cat is on the table.)

j. Saya taruh kucing itu di atas meja.

(I put the cat on the table.)

The elicitation results (5) show that, in details, the verbal descriptions given by the subjects vary. However, the spatial relation between the cat and the table was perceived the same by the subject. The perception of the spatial relation is a vertically oriented spatial relation with topangan topology.

The important question that draws attention from the elicitation results is why none of the subjects perceive the relationship between these entities with the verbal description of the preposition "di bawah" (under, below) so that it can be like the lingual realization (6).

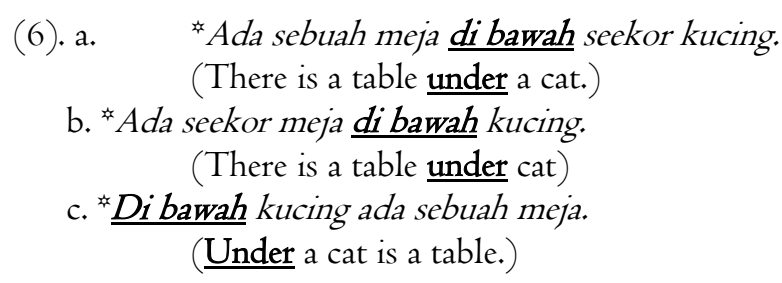

The verbal description (6) has a meaning that can represent the spatial relationship between the cat and the table in Figure 9. The verbal description image schema (6) is also a part of the VERTICALITY image schema. However, Indonesian speakers do not perceive the spatial relation in Figure 9 with the perception of the spatial relation with the prepositional topology "di bawah" as in the verbal description (6), but with the spatial relation with the prepositional topology "di atas" as in the verbal description (5) instead.

The elicitation result analysis indicates that spatially related entities can be perceived differently. Indonesian speakers perceive the cat entity and the table entity in Figure 9 with different positions. In other words, the position of the two entities is not symmetrical. This is the basic reason why the verbal descriptions (6) are not appropriate for Figure 9, even though its meaning can logically represent Figure 9. The asymmetrical position of the entities becomes one part of the conceptual structure of the prepositions in the VERTICALITY image schema.

The different positions of these entities show that speakers perceive that one entity has a more basic position than the other entity. Entities that are perceived to have a more basic position are used as the basis for their relational framework. Meanwhile, the other entity is used as a related figure. Based on the analysis of elicitation results in Figure 9, Indonesian speakers perceive the table entity as the basis and the cat entity as the figure. The relationship between the two in cognitive semantics is known as the relationship between Ground and Figure or between Landmark and Trajectory. In Figure 9, therefore, the table entity is perceived as the Landmark, while the cat entity is perceived as the Trajectory.

The speaker's asymmetrical perception of the associated entities is one of the important categorizations in the image schema for the preposition "di atas", both based on its orientation and topology. The different perception of the positions of the entities in this VERTICALITY image schema, in turn, results in the prepositions "di atas" and "di bawah". The orientation and topology in VERTICALITY image schema does not result in the prepositions "di atas" and "di bawah". The results of this analysis and discussion show the importance of further research on entity symmetry in spatial relations as well as the motives that make an entity in a spatial relation perceived as the Landmark while the other as the Trajectory.

\section{Extension of the Use of the Preposition "di atas" in Conceptual Mapping}

Up to this point, the non-lingual data displayed in the discussion is in the form of configurations of spatial relations between entities in the form of concrete entities. With concrete entity data, the image schema that forms the conceptual structure for the preposition "di atas" can be clearly identified. The image schema is a mental representation resulting from empirical experience. The VERTICALITY, TA, and TT image schemas can be easily correlated with empirical facts of various configurations of spatial relations using the preposition "di atas". However, the results of the data analysis show that the preposition "di atas" is also used to represent spatial relations in which there are abstract entities such as sample data (7). 
(7). a. Sedangkan, khusus bagi penumpang dengan usia di atas 50 tahun, petugas akan melakukan pengaturan tempat duduk. seat arrangements.)

(Meanwhile, specifically for passengers above the age of 50, the officers will make

\section{b. Perusahaan menetapkan harga di atas harga pasar.}

(The company sets a price above the market price.)

c. Fenomena alam kumpulan awan yang tampak dengan warna-warni yang indah sempat terlihat di atas langit kota Medan.

(The natural phenomenon of a collection of clouds that appear in beautiful colors was seen in the sky of Medan.)

d. membanguan pernikahan di atas dasar yang kokoh. (building a marriage on a solid foundation)

\section{kepentingan Partai.}

e. Kita doakan saja semoga sehat dan amanah untuk membela kepentingan negara di atas

\section{above the interests of the party.)}

(Let's just pray that (he) is fit and trustworthy to prioritize the interests of the nation

The use of the preposition "di atas" in the sample data (7) spatially relates two entities where both or one of which is an abstract entity. Two entities related by the preposition "di atas" in the sample data (7) are presented in the analysis results (8).

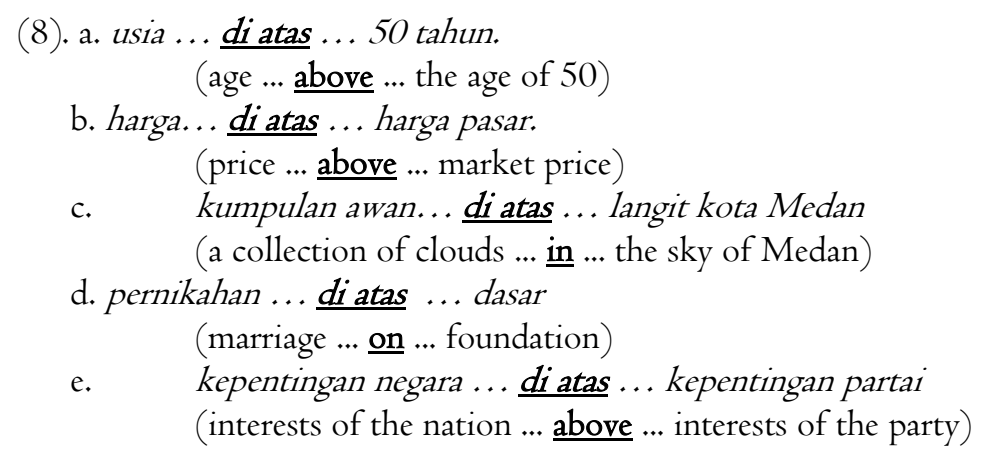

The abstract entity that is related in the sample data (8) does not represent the relationship between two entities that are physical, either based on its orientation or topology. The relation between the two entities is also abstract. It means that Indonesian speakers perceive the relations as in the example data (8) as the perception of relations between entities with the VERTICALITY image schema. In other words, the perception of vertical physical relations between entities is extended to relations between entities that are not physical.

The sample data (7) and (8) show that there are at least four extensions. First, the addition of a number is perceived as a vertical change in quantity. In the example data (7.a), it appears that the increase in age is perceived as a vertical increase in quantity. The same thing is also shown in the increase in price (7.b). Second, positive values as in (7.e) "kepentingan negara" (interests of the nation) are perceived vertically above the values that are perceived as not good in certain contexts. It means that the good is perceived vertically at the top and the bad is perceived vertically at the bottom. Third, space, in this case is "langit" (the sky), is perceived to have layers so as to allow statements such as in data example (7.c). Fourth, the household (marriage) is perceived as a building.

The extension of spatial relation perception is also carried out by speakers of other languages, such as English. There are several differences in the extension of the VERTICALITY image schema between Indonesian and English. In the extension of numbers, English provides explicit specifications with TA image schema instead of TT image schema, hence using the preposition "above" or "over" instead of the preposition "on". Meanwhile, regarding the extension of abstract entities as building entities, the English language explicitly specifies them with TT image schema. It is also an interesting topic to study in the cognition of Indonesian speakers. Another difference lies in how the sky is perceived. Indonesian speakers perceive the sky in the form of layers as shown in statement (7.c). Meanwhile, English speakers perceive the sky as a container. Therefore, in this case, English speakers do not use the prepositions "above", "over", or "on", but will use the preposition "in". This, once again, confirms that conceptualization of meaning is construal.

The extension of the use of the preposition "di atas" is in the form of mapping from a spatial relation concept with a physical VERTICALITY image schema to an abstract spatial relation concept that is perceived as 
physical spatial relation. In other words, the addition in numbers is mapped conceptually like a stack where it goes higher the more the number goes up. The same is true for the perception of marriage as a building that stands on a foundation and the sky that is made up of layers. This conceptual mapping occurs cognitively by mapping one phenomenon in a certain domain into another. The extension of the use of the preposition "di atas" is the result of mapping from vertical spatial relations between concrete entities to spatial relations that are conceptually similar to them. In cognitive semantics, this cognitive phenomenon is a process of forming metaphors. Therefore, the extension of the use of the preposition "di atas" is one of the realizations of metaphorical thoughts in the form of language. It also shows that prepositional lingual units also have an important role in structuring thoughts, unlike what has been previously believed that they are closed lingual units.

\section{Conclusion}

The results of this study can be formulated in three conclusions. First, this study on the spatial relation of the preposition "di atas" in cognitive semantic theory shows that the concept of meaning contained in prepositions is not as simple as what has been previously considered. The conceptual structure in the preposition "di atas" consists of an image schema based on orientation and topology. The speaker's perception of which entity is the Landmark will produce a reference point for the representation of its verticality and, subsequently, its topology. Second, to date, prepositions have been considered as lingual units that cannot be used metaphorically. The extension of the use of the preposition "di atas" in conceptual mapping clearly shows that prepositions can be used as a metaphorical lingual unit. Third, further research is needed to examine the topic in detail. Further research needed, among others, are research to determine the cognitive foundations for the determination of Landmark and Trajectory, research to determine the radius of the topology, and research to determine the patterns of its metaphorical extension.

\section{Funding}

This research was funded by DIPA fund of Medan State Polytechnic with contract Number B/218/PL5/PT.01.05/2020.

\section{REFERENCES}

Auer, P., \& Schmidt, J. E. (2010). Language and Space: An International Handbook of Linguistic Variation Volume I: Theories and Methods. Mouton de Gruyter. https://doi.org/I0.15I5/9783I 10220278

Brenda, M. (20I4). Cognitive perspective on the polysemy of the english spatial preposition over. Cambridge Scholar Publishing.

Chaer, A. (2008). Morfologi Bahasa Indonesia (Pendekatan Proses). Rineka Cipta.

Clark, A. (2010). Mind in space. In K. S. Mix, L. B. Smith, \& M. Gasser (Eds.), The Spatial Foundations of Language and Cognition (pp. 7-I5). Oxford University Press.

http://en.wikipedia.org/w/index.php?title=Andy_Clark\&oldid=534261752

Croft, W., \& Cruse, D. A. (2004). Cognitive Linguistics. Cambridge University Press.

DiMaggio, P. (1997). Culture and cognition. Annu. Rev. Social, 23, 263-287.

https://doi.org/I0.I038/25I454a0

Effendi, S., \& Aritonang, B. (I99I). Preposisi dan Frase Berpreposisi. Departemen Pendidikan dan Kebudayaan.

Evans, V. (2012). Language and time: A cognitive linguistics approach. In Language and Time: A Cognitive Linguistics Approach. https://doi.org/10.1017/CBO9781 107340626

Evans, V., \& Green, M. (2006). Cognitive Linguistics: An Introduction. Edinburg University Press.

Hampe, B., \& Grady, J. E. (2005). From Perception to Meaning: Image Schemas in Cognitive Linguistics. In B. Hampe \& J. E. Grady (Eds.), Image (Rochester, N.Y.). Mouton de Gruyter. http://books.google.com/books?id=W7rfPeliyOC

Hanif, A., Hardiyanti, S. U., \& Sumarlam. (2020). Frasa Preposisional dalam Kumpulan Cerpen Senja dan Cinta yang Berdarah Karya Seno Gumira Ajidarma. Seminar Nasional Linguistik Dan Sastra:, I38-I45.

Hickmann, M., \& Robert, S. (2006). Space, language, and cognition, some new challenges. In M. Hickmann \& S. Robert (Eds.), Space in Languages, Linguistic Systems and Cognitive Categories (pp. I - I8). John Benjamins.

Johnson, M. (1987). The Body in the Mind: The Bodily Basis of Meaning, Imagination, and Reason. In 2017 Joint Conference of the European Frequency and Time Forum and IEEE International Frequency Control Symposium, EFTF/IFC 2017 - Proceedings. University of Chicago Press. https://doi.org/I0.I I09/FCS.2017.8088869 
810.

Kurniasih. (2017). Penggunaan preposisi dalam bahasa indonesia. Jurnal Bahasa Dan Sastra Indonesia, 6(6), 798

Kusmanto, J. (20I7). The cognitive theory of spatial preposition and its application to teaching English as a foreign language and translation. In D. Rochsantiningsih, R. Hartono, \& M. Anugerahwati (Eds.), he 6th ELTLT CONFERENCE PROCEEDINGS. (Issue October, pp. 285-29I). FBS Unnes.

Levinson, S. C., \& Wilkins, D. P. (2006). The background of the study of the language of space. In S. C. Levinson \& D. P. Wilkins (Eds.), Grammars of Space: Explorations in Cognitive Diversity (pp. I-23). Cambridge University Press.

Mardiah, Z., \& Muta'ali, A. (2020). Preposisi spasial "pada” dalam tinjauan semantik kognitif. Seminar Internasional Riksa Bahasa XIII, 99I-998. http:// proceedings.upi.edu/index.php/riksabahasa/article/view/980

Mas Kusumaningrat, I. C. (20I5). Analisis konstrastif pemarkah lokatif “di” dalam bahasa Indonesia dan "in”, “on”, "at” dalam bahasa Inggris. Linguistika: Buletin Ilmiah Program Magister Linguistik Universitas Udayana, 22( I), 94 I07. https://ojs.unud.ac.id/index.php/linguistika/article/view/I4000

Medin, D. L. (1989). Concepts and conceptual structure. American Psychologist, 44(I2), I469-I48I. https://doi.org/I0.1037/0003-066X.44.12.1469

Mix, K. S., Smith, L. B., \& Gasser, M. (20I0). Thinking through space. In K. S. Mix, L. B. Smith, \& M. Gasser (Eds.), The Spatial Foundations of Language and Cognition (pp. I-6). Oxford University Press. https://doi.org/I0.1093/acprof:oso/9780199553242.00I.000I

Mix, K. s, Smith, L. B., \& Gasser, M. (2009). Thinking Through Space. In K. s Mix, L. B. Smith, \& M. Gasser (Eds.), The Spatial Foundations of Language and Cognition (pp. I-6). Oxford University Press.

Mulyadi. (20I2). Frasa preposisi bahasa Indoensia: analisis X-Bar. Kajian Sastra, 34(I), I-I2. https://ejournal.undip.ac.id/index.php/kajiansastra/article/view/267I

Munnich, E., Landau, B., \& Anne, B. (200I). Spatial language and spatial representation : a cross-linguistic comparison. 81 .

Payne, T. E. (20I I). Understanding English Grammar: A Linguistic Introduction. Cambridge University Press. http://libraryI.nida.ac.th/termpaper6/sd/2554/I9755.pdf

Rini, E. I. H. A. N. (2009). Analisis kontrastif pemarkah lokatif "di” dalam bahasa Indonesia dengan "ni” dan "de" dalam bahasa Jepang. Komposisi: Jurnal Pendidikan, Bahasa, Dan Seni, IO(2), 8I-88.

Rosch, E. (1978). Principles of categorization. In E. Rosch \& B. L. Lloyd (Eds.), Cognition and categorization (pp. 27-48). Lawrence Erlbaum.

Sharifian, F. (20I I). Cultural Conceptualisations and Language. John Benjamins Publishing Company.

Sugiarti, R., \& Ngaisah, S. (2018). Analisis kesalahan penggunaan preposisi dan pungtuasi dalam karangan narasi siswa. Primary: Jurnal Keilmuan Dan Kependidikan Dasar, IO22), I25-I34.

https://doi.org/I0.32678/primary.vIOiO2.I284

Svorou, S. (1994). The Grammar of Space. John Benjamins Pub. Co.

Talmy, L. (1983). How language structures space. In H. Pick \& L. Acredolo (Eds.), Spatial Orientation: Theory, Research, and Application (pp. 225-282). Plenum Press.

Talmy, L. (2000). Toward a Cognitive Semantics. MIT Press.

Tyler, A., \& Evans, V. (2003). The Semantics of English Prepositions: Spatial Scenes, Embodied Meaning and Cognition. https://doi.org/I0.1007/sI3398-0I4-0173-7.2

van Gelderen, E. (20I0). An introduction to the grammar of English (Revised). John Benjamins Pub. Co. https://doi.org/I0.1075/z.I53

Yusof, M. (1996). Fungsi frasa preposisi : predikatif lawan non-predikatif * Linguistik Indonesia, 27(2), 197-2I5.

Zlatev, J. (2007). Spatial semantics. In D. Geeraerts \& H. Cuyckens (Eds.), The Oxford Handbook of Cognitive Linguistics (pp. 318 - 350). Oxford University Press. 